\title{
Pengaruh Daya Tarik Iklan Shopee di Televisi terhadap Minat Beli Berdasarkan Elaboration Likelihood Model di Lingkungan Mahasiswa Ilmu Komunikasi UMN Angkatan 2016
}

\author{
David Ricardo, Yugih Setyanto, Anto Sudarto \\ davidricardo2903@gmail.com,Yugihs@fikom.untar.ac.id,Antosudarto@gmail.com
}

Fakultas Ilmu Komunikasi Universitas Tarumanagara

\begin{abstract}
The purpose of this study was to determine the effect of the attractiveness of Shopee Advertising on television on buying interest based on ELM in the Communication Sciences UMN Class of 2016. The research method used was quantitative, namely by using a statistical approach, a sample of 190 people. From the results of calculations using SPSS, it is known that the correlation coefficient ( $r$ ) of 0.803 means that the influence between Ad Creativity, Attractiveness of Celebrity Endorser and Credibility of Celebrity Endorser on Buying Interest is very strong. The results showed 1) There was a significant influence between Advertising Creativity on Purchase Interest, this was evidenced by the results of the significance value in the $T$ test of $0.00<0.05$; 2) There is no significant influence between the attractiveness of Celebrity Endorser on buying interest, this is evidenced by the results of the significance value in the $T$ test of $0.123>0.05 ; 3)$ There is a significant influence between the credibility of Celebrity Endorser on Purchase Interest, this is evidenced by the results of the significance value in the T test of $0.00<0.05$; 4) There is a significant influence of Advertising Creativity, Attractiveness of Celebrity Endorser and Credibility of Celebrity Endorser together on buying interest, this is evidenced by the significant value on the F test of $0.00<0.05$.
\end{abstract}

Keywords: attractiveness of advertisements, buying interest

\begin{abstract}
Abstrak
Tujuan penelitian untuk mengetahui Pengaruh Daya Tarik Iklan Shopee Di Televisi Terhadap Minat Beli Berdasarkan ELM Di Lingkungan Mahasiswa Ilmu Komunikasi UMN Angkatan 2016. Metode penelitian yang digunakan kuantitatif, yaitu dengan menggunakan pendekatan statistik, sampel yang digunakan sebanyak 190 orang. Dari hasil perhitungan dengan menggunakan SPSS, diketahui nilai koefisien korelasi (r) sebesar 0,803 artinya pengaruh antara Kreativitas Iklan, Daya tarik dan Kredibilitas terhadap Minat Beli adalah sangat kuat. Hasil penelitian menunjukkan 1) Terdapat pengaruh yang signifikan antara Kreativitas Iklan terhadap Minat Beli, hal ini dibuktikan dengan hasil nilai signifikansi pada uji T sebesar 0,00 $<0,05 ; 2)$ Tidak terdapat pengaruh yang signifikan antara Daya tarik Celebrity Endorser terhadap Minat beli, hal ini dibuktikan dengan hasil nilai signifikansi pada uji T sebesar 0,123 $>0,05 ; 3)$ Terdapat pengaruh yang signifikan antara Kredibilitas Celebrity Endorser terhadap Minat Beli, hal ini dibuktikan dengan hasil nilai signifikansi pada uji T sebesar $0,00<0,05$; 4) Terdapat pengaruh yang signifikan Kreativitas Iklan, Daya tarik dan Kredibilitas secara bersama-sama terhadap Minat beli, hal ini dibuktikan dengan nilai signifikan pada uji $\mathrm{F}$ sebesar $0,00<0,05$.
\end{abstract}

Kata Kunci: daya tarik, minat beli 


\section{Pendahuluan}

Pada sekarang ini periklanan menjadi penting bagi perusahaan dimana iklan dapat menghasilkan suatu karya yang akan nantinya menjadi pemasukan yang tinggi. Rumusan masalahnya adalah: 1) Seberapa besar Pengaruh Kreativitas Iklan Shopee di Televisi Terhadap Minat Beli Berdasarkan ELM di Lingkungan Mahasiswa Ilmu Komunikasi UMN Angkatan 2016, 2) Seberapa besar Pengaruh Daya Tarik $C E$ iklan Shopee di Televisi Terhadap Minat Beli Berdasarkan ELM di Lingkungan Mahasiswa Ilmu Komunikasi UMN Angkatan 2016, 3) Seberapa besar Pengaruh Kredibilitas $C E$ Iklan Shopee di Televisi Terhadap Minat Beli Berdasarkan ELM di Lingkungan Mahasiswa Ilmu Komunikasi UMN Angkatan 2016, 4) Seberapa besar Pengaruh Kreativitas iklan, Daya Tarik $C E$, dan Kredibilitas $C E$ Iklan Shopee di Televisi Terhadap Minat Beli Berdasarkan ELM di Lingkungan Mahasiswa Ilmu Komunikasi UMN Angkatan 2016.

Tujuan penelitiannya adalah: 1) Untuk mengetahui seberapa besar Pengaruh Kreativitas Iklan Shopee di Televisi Terhadap Minat Beli Berdasarkan ELM di Lingkungan Mahasiswa Ilmu Komunikasi UMN Angkatan 2016. 2) Untuk mengetahui seberapa besar Pengaruh Daya Tarik $C E$ iklan Shopee di Televisi Terhadap Minat Beli Berdasarkan ELM di Lingkungan Mahasiswa Ilmu Komunikasi UMN Angkatan 2016. 3) Untuk mengetahui seberapa besar Pengaruh Kredibilitas $C E$ Iklan Shopee di Televisi Terhadap Minat Beli Berdasarkan ELM di Lingkungan Mahasiswa Ilmu Komunikasi UMN Angkatan 2016. 4) Untuk mengetahui seberapa besar Pengaruh Kreativitas iklan, Daya Tarik $C E$, dan Kredibilitas $C E$ Iklan Shopee di Televisi Terhadap Minat Beli Berdasarkan ELM di Lingkungan Mahasiswa Ilmu Komunikasi UMN Angkatan 2016.

\section{Hipotesis penelitian :}

- Pengaruh kreativitas iklan terhadap minat beli

$\mathrm{H}_{0}$ : tidak ada pengaruh kreatifitas iklan terhadap minat beli

$\mathrm{H}_{1}$ : ada pengaruh kreatifitas iklan terhadap minat beli

- Pengaruh Daya tarik $C E$ terhadap minat beli

$\mathrm{H}_{0}$ : tidak ada pengaruh daya tarik $C E$ terhadap minat beli

$\mathrm{H}_{1}$ : ada pengaruh daya tarik $C E$ terhadap minat beli

- Pengaruh kredibilitas celebrity endorser terhadap minat beli

$\mathrm{H}_{0}$ : tidak ada pengaruh kredibilitas $C E$ terhadap minat beli

$\mathrm{H}_{1}$ : ada pengaruh kredibilitas $C E$ terhadap minat beli

\section{Kreativitas Iklan}

Iklan yang kreatif adalah iklan yang ori dan tidak ada unsur kemiripan dengan iklan lain, iklan yang tidak kita duga, iklan yang tidak kita sangka, iklan yang memiliki pengertian atau arti dan iklan yang dapat mempengaruhi tingkat emosi kita (Swastha, 2000).

\section{Celebrity endorser}

Shimp 2003 (dalam Mulyawati, 2015) menyatakan bahwa celebrity endorser merupakan salah satu pilihan yang digunakan untuk mengiklankan suatu produk dengan memanfaatkan seseorang yang memiliki ketenaran atau dikenal dikalangan masyarakat luas sehingga dapat membantu produk tersebut agar diketahui orang banyak. Pesan dalam suatu produk dan jasa yang bertujuan untuk kegiatan promosi 
David Ricardo, Yugih Setyanto, Anto Sudarto: Pengaruh Daya Tarik Iklan Shopee di Televisi terhadap Minat Beli Berdasarkan Elaboration Likelihood Model di Lingkungan Mahasiswa Ilmu Komunikasi UMN Angkatan 2016

dengan menggunakan seseorang atau icon yang memiliki ketenaran yang diketahui oleh menyampaikan banyak orang disebut juga endorser (Saragih, Pangestuti, dan Devita, 2018).

\section{Daya tarik Celebrity Endorser} antara lain:

Sub variabel daya tarik menurut Shimp (2003) memiliki beberapa atribut,

1. Likeability: Konsumen akan lebih menyukai suatu celebrity apabila ia telah sering melihatnya. Hal ini penting karena penting bagi suatu merek untuk memilih celebrity endorser dan menyadari seberapa akrab konsumen dengan endorser tersebut.

2. Similarity (tingkat kesamaan): Seseorang akan lebih mudah untuk dipengaruhi apabila ia menyadari ada kemiripan dalam beberapa faktor, kemiripan ini dapat berupa dalam hal kesukaan, cara berpakaian, olahraga, maka konsumen akan berusaha untuk mencoba meniru seorang endorser.

3. Familiarity (tingkat pengenalan audience): Konsumen akan lebih menyukai suatu selebriti apabila ia telah sering melihat selebriti tersebut.

\section{Kredibilitas Celebrity Endorser}

Kredibilitas Celebrity Endorser ini diturunkan menjadi menarik, terpercaya, keahlian. Menurut Cangara (dalam Erdiansyah, 2019) menyatakan, kredibilitas dapat diperoleh jika celebrity endorser mempunyai ethos, pathos, dan logos. Ethos adalah keahlian celebrity endorser dari karakter dirinya dapat membuat kata-katanya bisa di percaya. Pathos merupakan keahlian celebrity endorser dalam mengendalikan emosi penonton, dan Logos merupakan keterampilan celebrity endorser melalui penampilannya.

\section{Minat Beli} motivasi.

Minat muncul karena adanya stimulus motif yang nantinya menimbulkan

\section{Metode Penelitian}

Penulis menggunakan penelitian kuantitatif. Dimana menggunakan perhitungan menggunakan angka atau menggunakan teknik statistik. Penulis menggunakan metode survey.

Populasi adalah sekumpulan obyek/subyek yang akan diteliti, dalam penelitian ini penulis memilih para konsumen atau individu yang sudah melihat iklan Shopee di televisi yang dibawakan oleh Via Vallen yang ditujukan kepada mahasiswa Ilmu Komunikasi UMN angkatan 2016.

Sampel adalah bagian kecil dari populasi yang terpilih, sehingga sampel bertugas untuk mewakilkan seluruh dari populasi yang ada sehingga tidak memerlukan waktu dan tenaga lebih (Sugiyono, 2016).

Peneliti memilih untuk menggunakan metode sampling insidental yaitu teknik sampling yang menentukan sampelnya secara kebetulan dan siapa saja yang menurut peneliti cocok maka dapat dijadikan sampel dalam penelitian (Sugiyono,2016). Roscoe mengatakan di bukunya tahun 2006 (dalam jurnal Dennyka dan Erdiansyah, 2017) bahwa sampel sebaiknya lebih dari angka 30 dan juga harus kurang dari 500 
diyakini tepat untuk suatu penelitian. Sehingga penulis menggunakan jumlah sampel sebanyak 190 orang.

Pada penelitian ini penulis menggunakan metode pengumpulan data dengan angket atau kuesioner.. Kuesioner ini berisi pertanyaan-pertanyaan yang berhubungan dengan variabel-variabel yang akan diteliti dalam penelitian ini. Kuesioner ini akan penulis sebarkan kepada responden yaitu mahasiswa Ilmu Komunikasi UMN angkatan 2016, penulis akan menyebarkan kuesioner melalui google form kepada mahasiswa Ilmu Komunikasi UMN angkatan 2016.

Dalam penelitian ini penulis menggunakan teknik SPSS untuk membantu mencari hasil peneliti. Pada penelitian ini, peneliti ingin menguji validitas hasil kuesioner dari indikator-indikator dari variabel $\mathrm{X}$ yaitu kreativitas iklan, daya tarik celebrity endorser, kreativitas celebrity endorser, serta variabel $\mathrm{Y}$ yaitu minat beli. Tujuan dari pengukuran ini menggunakan uji reliabilitas dilakukan dengan maksud agar variabel-variabel dalam penelitian ini dapat terbukti dan dipercaya kebenarannya. Ghozali (2016) mengatakan suatu instrumen dalam penelitian dapat dinyatakan reliabel apabila memiliki nilai Cronbach's Alpha lebih dari 0.6 dan bila nilai Cronbach's Alpha suatu instrument kurang dari 0.6 maka tidak reliable. Sarjono dan Julianita (2011) menyebutkan bahwa suatu data yang dianggap tidak valid atau tidak reliabel harus diganti dengan data yang lain karena data tersebut tidak dapat digunakan dalam penelitian.

Suatu instrumen penelitian dapat dinyatakan reliabel apabila (Ghozali, 2012:133) :

1) Jika hasil koefisien $>0,60$, maka instrumen ditentukan reliabel.

2) Jika hasil koefisien $\leq 0,60$, maka instrumen ditentukan tidak reliabel.

Menurut Bungin (2015), istilah korelasi dikenal sebagai nilai hubungan antara dua atau lebih variabel yang diteliti. Nilai koefisien harus juga signifikansi, digunakan untuk menentukan suatu hipotesis dapat diterima atau ditolak.

Tabel 1. Nilai Koefisien Korelasi

\begin{tabular}{cc}
\hline Nilai Koefisien & Penjelasannya \\
\hline Kurang dari 0,20 & Hubungan rendah sekali ; lemah sekali \\
\hline $0,20-0,40$ & Hubungan rendah tetapi pasti \\
\hline $0,40-0,60$ & Hubungan yang cukup berarti \\
\hline $0,61-0,80$ & Hubungan yang tinggi; kuat \\
\hline $0,81-1,00$ & Hubungan sangat tinggi; kuat sekali, dapat diandalkan \\
\hline & (Sumber: Rakhmat, 2015: 29)
\end{tabular}

Koefisiensi determinasi $\left(\mathrm{R}^{2}\right)$ bertujuan untuk mengetahui seberapa besar kemampuan variabel independen (Kreativitas iklan, Daya tarik $C E$, Kreativitas $C E$ ) menjelaskan variabel dependen (minat beli). Untuk mendeteksi ada atau tidaknya normalitas, dapat dilakukan dengan melihat Normal Probability Plot dari SPSS. Menurut Ghozali uji heteroskedastisitas bertujuan untuk menguji apakah di dalam model regresi terjadi ketidaksamaan variance dari residual satu pengamatan ke pengamatan yang lain. Uji multikolinieritas dilakukan untuk menguji apakah dalam model regresi ditemukan adanya korelasi antar variabel bebas. Pengambilan keputusan hasil DW adalah sebagai berikut; 
David Ricardo, Yugih Setyanto, Anto Sudarto: Pengaruh Daya Tarik Iklan Shopee di Televisi terhadap Minat Beli Berdasarkan Elaboration Likelihood Model di Lingkungan Mahasiswa Ilmu Komunikasi UMN Angkatan 2016

\begin{tabular}{lll}
\hline \multicolumn{1}{c}{ Kriteria } & \multicolumn{1}{c}{$\mathrm{H}_{\mathrm{o}}$} & \multicolumn{1}{c}{ Keputusan } \\
\hline $0<\mathrm{DWdL}$ & Ditolak & Ada autokorelasi \\
\hline $\mathrm{dL}<\mathrm{DW}<\mathrm{dU}$ & Tidak ada keputusan & Tidak ada keputusan \\
\hline 4-d $<\mathrm{DW}<4$ & Ditolak & Ada autokorelasi \\
\hline 4-dU $<\mathrm{DW}<4-\mathrm{dL}$ & Tidak ada keputusan & Tidak ada keputusan \\
\hline $\mathrm{d} \mathrm{U}<\mathrm{DW}<4-\mathrm{dU}$ & Diterima & Tidak ada korelasi \\
\hline
\end{tabular}

\section{Hasil Temuan dan Diskusi}

\section{Pengaruh Kreativitas Iklan, Daya tarik Celebrity Endorser dan Kredibilitas Celebrity Endorser terhadap Minat Beli}

Analisis kontribusi variabel Kreativitas Iklan, Daya tarik Celebrity Endorser dan Kredibilitas Celebrity Endorser terhadap Minat Beli memperlihatkan hasil perhitungan yang signifikan. Pengaruh variabel $\mathrm{X}_{1}, \mathrm{X}_{2}, \mathrm{X}_{3}$ terhadap Minat beli bersifat signifikan pada tingkat taraf kepercayaan 95\%, sehingga berlaku universal.

Dari hasil perhitungan dengan SPSS diperoleh nilai koefisien korelasi sebesar 0,803 maka dapat dikatakan bahwa pengaruh variabel Kreativitas Iklan, Daya tarik Celebrity Endorser dan Kredibilitas Celebrity Endorser terhadap Minat Beli adalah sangat kuat. Hal ini ditunjukkan dengan jawaban responden yang mayoritas setuju. Sedangkan nilai koefisien determinasi sebesar 0,640 yang menunjukkan bahwa besarnya pengaruh variabel Kreativitas Iklan, Daya tarik Celebrity Endorser dan Kredibilitas Celebrity Endorser terhadap Minat Beli adalah 64\% sedangkan sisanya dipengaruhi oleh variabel lain.

Tingkat signifikan pada uji F sebesar 0,00 sehingga dapat dikatakan Kreativitas Iklan, Daya tarik Celebrity Endorser dan Kredibilitas Celebrity Endorser secara bersama-sama berpengaruh terhadap Minat Beli, karena hal ini ini dibuktikan dengan jawaban responden pada Kreativitas Iklan, Daya tarik Celebrity Endorser dan Kredibilitas Celebrity Endorser yang mayoritas adalah setuju.

\section{Pengaruh Kreativitas Iklan terhadap Minat Beli}

Analisis kontribusi variabel Kreativitas Iklan $\left(\mathrm{X}_{1}\right)$ terhadap Minat Beli memperlihatkan hasil perhitungan yang signifikan. Pengaruh variable $\mathrm{X}_{1}$, terhadap Minat Beli bersifat signifikan pada tingkat taraf kepercayaan 95\%, sehingga berlaku universal.

Dari hasil perhitungan dengan SPSS diperoleh nilai koefisien korelasi sebesar 0,660 maka dapat dikatakan bahwa pengaruh variabel Kreativitas Iklan $\left(\mathrm{X}_{1}\right)$ terhadap Minat Beli adalah kuat dan meningkat. Hal ini ditunjukkan dengan jawaban responden yang mayoritas setuju.

Tingkat signifikan pada uji $\mathrm{t}_{1}$ sebesar 0,00 sehingga dapat dikatakan Kreativitas Iklan berpengaruh signifikan terhadap Minat beli, Karena hal ini dibuktikan dengan jawaban responden yang mayoritas adalah setuju.

\section{Pengaruh Daya Tarik Celebrity Endorser terhadap Minat Beli}

Analisis kontribusi variabel Daya Tarik Celebrity Endorser $\left(\mathrm{X}_{2}\right)$ terhadap Minat Beli memperlihatkan hasil perhitungan yang tidak signifikan. Pengaruh variabel $\mathrm{X}_{2}$, terhadap Minat Beli bersifat tidak signifikan pada tingkat taraf kepercayaan $95 \%$, sehingga berlaku universal. 
Dari hasil perhitungan dengan SPSS diperoleh nilai koefisien korelasi sebesar 0,564 maka dapat dikatakan bahwa pengaruh variabel Daya Tarik Celebrity Endorser $\left(\mathrm{X}_{2}\right)$ terhadap Minat Beli adalah sedang.

Tingkat signifikan pada uji $\mathrm{t}_{1}$ sebesar 0,123 sehingga dapat dikatakan Daya Tarik Celebrity Endorser tidak berpengaruh signifikan terhadap Minat beli.

\section{Pengaruh Kredibilitas Celebrity Endorser terhadap Minat Beli}

Analisis kontribusi variabel Kredibilitas Celebrity Endorser $\left(\mathrm{X}_{3}\right)$ terhadap Minat Beli memperlihatkan hasil perhitungan yang signifikan. Pengaruh variabel $\mathrm{X}_{3}$, terhadap Minat Beli bersifat signifikan pada tingkat taraf kepercayaan 95\%, sehingga berlaku universal.

Dari hasil perhitungan dengan SPSS diperoleh nilai koefisien korelasi sebesar 0,770 maka dapat dikatakan bahwa pengaruh variabel Kredibilitas Celebrity Endorser $\left(\mathrm{X}_{3}\right)$ terhadap Minat Beli adalah kuat dan meningkat. Hal ini ditunjukkan dengan jawaban responden yang mayoritas setuju.

Tingkat signifikan pada uji $\mathrm{t}_{1}$ sebesar 0,00 sehingga dapat dikatakan Kredibilitas Celebrity Endorser berpengaruh signifikan terhadap Minat beli, Karena hal ini dibuktikan dengan jawaban responden yang mayoritas adalah setuju.

\section{Temuan Penelitian}

Hasil penelitian berdasarkan statistik eksplanatif menunjukkan responden lebih menjawab setuju dihasil jawaban.

1. Terdapat pengaruh $\mathrm{X}_{1}$ terhadap $\mathrm{Y}$. Hal ini ditunjukkan dengan jawab responden yang mayoritas setuju.

2. Tidak terdapat pengaruh variabel Daya tarik Celebrity Endorser $\left(\mathrm{X}_{2}\right)$ terhadap Minat Beli.

3. Terdapat pengaruh variabel $\mathrm{X}_{3}$ terhadap $\mathrm{Y}$. Hal ini ditunjukkan dengan jawaban responden yang mayoritas setuju.

4. Terdapat pengaruh variabel $X_{1}, X_{2}, X_{3}$ secara bersama-sama terhadap Y. Hal ini ditunjukkan dengan jawaban responden yang mayoritas setuju.

\section{Kesimpulan}

1. Terdapat pengaruh signifikan antara $\mathrm{X}_{1}$ dengan $\mathrm{Y}$, hal ini dibuktikan dengan hasil nilai signifikansi pada uji $\mathrm{T}$ sebesar $0,00<0,05$.

2. Tidak terdapat pengaruh yang signifikan antara $X_{2}$ terhadap $Y$, hal ini dibuktikan dengan hasil nilai signifikansi pada uji $\mathrm{T}$ sebesar $0,123>$ nol koma nol lima

3. Terdapat pengaruh yang signifikan antara $X_{3}$ terhadap $Y$, hal ini dibuktikan dengan hasil nilai signifikansi pada uji T sebesar $0,00<$ nol koma nol lima

4. Terdapat pengaruh yang signifikan $X_{1}, X_{2}$ dan $X_{3}$ secara bersama-sama terhadap $\mathrm{Y}$, buktinya adalah nilai signifikan pada uji $\mathrm{F}$ sebesar $0,00<0,05$.

\section{Saran-Saran :}

1. Kreativitas iklan yang lebih baik serta mengajak kepada para pelanggan untuk membeli suatu produk hendaknya selalu ditingkatkan, sehingga akan diharapkan para pembeli di kemudian hari akan meningkat pula. 
2. Hendaknya perusahaan dalam memilih seorang celebrity endorser harus dilakukan secara selektif, yaitu mengenai latar belakang celebrity endorser serta riwayat atau asal usul harus diketahui dari mana asalnya, serta tidak pernah terlibat dalam penggunaan obat-obat terlarang.

3. Dalam memilih seorang celebrity endorser, perusahaan hendaknya menekankan tentang kredibilitas artis tersebut, sehingga diharapkan dapat meningkatkan daya tarik iklan.

\section{Ucapan Terima Kasih}

Peneliti berterima kasih pada:

a) Tuhan Maha Esa

b) Keluarga, teman, sahabat Peneliti yang senantiasa memberi dukungan dan mendoakan Peneliti.

\section{Daftar Pustaka}

A, Shimp,Terence (2003). Periklanan Promosi \& Aspek Tambahan Komunikasi Pemasaran.Terpadu, Jilid I ( edisi 5), Jakarta: Erlangga.

Agus, I. (2014). Statistik Konsep Dasar dan Aplikasinya. Jakarta: Prenada Media.

Bungin, Burhan. (2015). Metodologi Penelitian Kualitatif. Jakarta : Rajawali Pers.

Ghozali, Imam. (2016). Aplikasi Analisis Multi variete dengan Program IBM SPSS 23 (Edisi 8). Cetakan ke VIII. Semarang : Badan Penerbit Universitas Diponegoro.

Ghozali, Imam. (2012). Aplikasi Analisis Multivariate dengan Program IBM SPSS. Yogyakarta: Universitas Diponegoro

Rakhmat,Jalaluddin. (2014) .Metode Penelitian Komunikasi. Bandung: PT. Remaja Rosdakarya.

Rakhmat, Jalaludin. (2015). Metode Penelitian Komunikasi.Bandung : PT Remaja Rosdakarya.

Riduwan, (2016).Dasar-Dasar Statistika, Alfabeta, Bandung.

Savitri, S. A., Erdiansyah, R. (2019). Pengaruh Citra, Kredibilitas, dan Kemampuan Komunikasi Beauty Vlogger terhadap Keputusan Pembelian Produk Makeup Maybelline (Studi Kasus tasya Farasya). Prologia, 3(1). 267-273.

Saragih, D.V.C., Pangestuti, E., \& Devita, L.D.R. (2018). Pengaruh Perceived Value, Celebrity Endorser dan Advertising terhadap Brand Attitude (Survei pada Mahasiswi Universitas Brawijaya Pengguna Kosmetik Wardah). Jurnal Administrasi Bisnis, 64(1), 2.

Sarjono, Haryadi., dan Julianita, Winda. (2011). SPSS vs LISREL: Sebuah Pengantar, Aplikasi untuk Riset. Penerbit Salemba empat, Jakarta.

Sugiyono, (2014).Metode Penelitian Bisnis (MPB), Jakarta: Alfabeta.

Sugiyono.Prof Dr. (2016) . Metode Penelitian Kuantitatif, Kualitatif dan $R \& D . P e n e r b i t$ : New Media: a Critical Introduction, Second Edition, New York: Routledge.

Swastha, Basu. 2000. Pengantar Bisnis Modern, Pengantar Ekonomi Perusahaan Modern, Jakarta : Liberty. 